\title{
Implementation of History Learning Through the Example of Buya A. R. Sutan Mansur in SMA Muhammadiyah 3 Surakarta
}

\author{
Ihsan' Hermanu Joebagio, Sariyatun \\ Universitas Sebelas Maret \\ insan.1111@yahoo.com
}

\author{
Article History \\ accepted 1/09/2020
}

approved 4/10/2020

published 1/12/2020

\begin{abstract}
This study aims to examine:1.) Implementation of Historical Learning through the Exemplary of Buya A. R. Sutan Mansur in SMA Muhammadiyah 3 Surakarta. 2.) Teachers' Constraints in Implementing History Learning at SMA Muhammadiyah 3 Surakarta. This study uses a qualitative method with a Discourse Analysis approach. Data were collected through observation, in-depth interviews, and documentation study. Data analysis techniques used interactive analysis by Milles and Huberman. The results of this study indicate:(1) The implementation of historical learning through the example of Buya AR Sutan Mansur at SMA Muhammadiyah 3 Surakarta has been running quite well and effectively, during the Covid 19 Pandemic through Google Classroom, in history learning the teacher has compiled a learning tool consisting of a syllabus, RPP and the application of Buya AR Sutan Mansur's exemplary values in the history of teacher learning have brought out the exemplary values of Buya AR Sutan Mansur which consist of religious values, nationalism values, hard work values, independence values and very high steadfastness.(2.) Teachers' Constraints in Implementing History Learning at SMA Muhammadiyah 3 Surakarta, namely inadequate learning resources, and insufficient learning time, while the subject matter is large, due to the different character of students.
\end{abstract}

Keywords: Buya A. R. Sutan Mansur, learning history

\begin{abstract}
Abstrak
Penelitian ini bertujuan untuk Mengkaji:1.) Implementasi Pembelajaran Sejarah Melalui Keteladanan Buya A. R. Sutan Mansur di SMA Muhammadiyah 3 Surakarta. 2.) Kendala Guru Dalam Implementasikan Pembelajaran Sejarah di SMA Muhammadiyah 3 Surakarta. Penelitian ini menggunakan Metode Kualitatif dengan pendekatan Discourse Analysis. Data dikumpulkan melalui observasi, wawancara secara mendalam, studi dokumentasi. Tekni Analisis data menggunakan analisis interaktif Milles dan Huberman. Hasil Penelitian ini menunjukkan:(1.) Implementasi Pembelajaran Sejarah Melalui Keteladanan Buya A. R. Sutan Mansur di SMA Muhammadiyah 3 Surakarta sudah berjalan cukup baik dan efektif, selama Pandemi Covid 19 melalui Google Classroom, dalam pembelajaran Sejarah guru sudah menyusun perangkat pembelajaran yang terdiri dari Silabus, RPP dan penerapan nilai-nilai keteladanan Buya A. R. Sutan Mansur dalam pembelajaran guru Sejarah sudah memunculkan nilai-nilai keteladanan Buya A. R. Sutan Mansur yang terdiri dari nilai Religius, nilai nasionalisme, nilai kerja keras, nilai kemandirian dan keteguhan pendirian yang sangat tinggi. (2.) Kendala Guru Dalam Implementasikan Pembelajaran Sejarah di SMA Muhammadiyah 3 Surakarta, yakni sumber belajar yang kurang memadai, serta waktu pembelajaran yang kurang mecukupi, sedangkan materi pelajarannya banyak, dikarenakan juga karakter Siswa yang berbeda-beda.
\end{abstract}

Kata Kunci: Buya A. R. Sutan Mansur, pembelajaran sejarah

$\begin{array}{lr}\text { Social, Humanities, and Education Studies (SHEs): Conference Series } & p-I S S N ~ 2620-9284 \\ \text { https://jurnal.uns.ac.id/shes } & \text { e-ISSN 2620-9292 }\end{array}$ 


\section{PENDAHULUAN}

Perkembangan ilmu pengetahuan, teknologi dan harus globalisasi telah berdampak pada perubahan dihampir semua aspek kehidupan manusia. Dalam upaya menghadapi berbagai permasalahan yang timbul akibat proses globalisasi pada satu pihak, dan proses demokratisasi pada pihak lain, sangat diperlukan sumber daya manusia yang lebih berkualitas melalui pembaharuan sistem pendidikan dan penyempurnaan Kurikulum di Indonesia, termasuk pada pembaharuan Kurikulum sejarah yang berbasis Kompetensi, demokratisasi dan berwawasan lokal namun tetap memperhatikan Standar Nasional (Suryadi dan Budiansyah. 2009)

Pendidikan merupakan hal yang penting bagi kehidupan berbangsa dan bernegara. Pendidikan mempengaruhi berbagai aspek dalam suatu negara diantaranya aspek sosial, politik dan ekonomi. Pendidikan berkaitan langsung dengan pembentukan manusia yang memiliki interaksi antara pendidik dan yang terdidik untuk mencapai tujuan pendidikan (Sukmadinata 2009). Tujuan pendidikan yang dituangkan dalam Undang-Undang No. 20. Tahun 2003 Pasal 3 yang menyebutkan bahwa,"Pendidikan Nasional berfungsi mengembangkan kemampuan dan membentuk watak serta peradaban bangsa yang bermartabat dalam rangka mencerdaskan kehidupan bangsa, serta bertujuan untuk berkembangnya potensi Siswa agar menjadi manusia yang beriman dan bertaqwa kepada Tuhan Yang Maha Esa, berakhlak mulia, sehat, berilmu, cakap, kreatif, mandiri dan mampu menjadi warga negara yang demokratis dan bertanggung jawab.

Pendidikan dapat mengembangkan kemampuan dan membentuk watak serta peradaban. Hal ini tidak akan terwujud apabila Siswa mendapatkan pembelajaran yang tidak tepat sasaran. Untuk itu perlu dilakukan peningkatan kualitas pembelajaran, peningkatan kualitas pembelajaran harus dilakukan secara terus menerus dan berkesinambungan. Peningkatan kualitas pembelajaran yang penting dalam penanaman watak kebangsaan seperti yang tercantum dalam UU No. 20 Tahun 2003 dapat dicapai melalui pembelajaran sejarah. Pembelajaran adalah proses kerja sama antara guru dan Siswa dalam memanfaatkan segala potensi dan sumber yang ada, baik itu, potensi yang bersumber dari dalam diri Siswa maupun potensi yang ada diluar diri Siswa sebagai upaya untuk mencapai tujuan belajar (Agung, Leo \& Wahyuni 2013), sedangkan sejarah merupakan cabang ilmu pengetahuan yang menelaah tentang asal usul dan perkembangan serta peranan masyarakat di masa lampau berdasarkan metode dan metodologi tertentu. Pengetahuan masa lampau tersebut mengadung nilainilai kearifan yang dapat digunakan dalam melatih kecerdasan, membentuk sikap, watak dan kepribadian Siswa (Aman 2011).

Pembelajaran sejarah adalah suatu upaya yang telah dirancang oleh pendidik untuk bisa mengaplikasikan baik berupa, ilmu pengetahuan, sikap serta nilai-nilai yang menyangkut suatu perubahan dan pertumbuhan masyarakat masa lampau hingga masa kini pada siswa agar dapat terterapkan dalam kehidupannya. Pembelajaran sejarah bukan saja memberikan sebuah pengetahuan sejarah terkait informasi, akan tetapi pembelajaran sejarah juga dapat membangkitkan kesadaran serta memperoleh nilainilai dari suatu peristiwa sejarah, pegetahuan sejarah diperlukan bagi semua orang sejak dini agar tahu serta paham tentang makna suatu peristiwa masa lalu dan dapat dijadikan sebagai landasan dalam bersikap dan mampu melihat kenyataan pada masa yang akan datang, maka perlunya sejarah dipelajari sejak dini oleh setiap orang baik formal maupun informal (Amin. S. 2010).

Sebagaimana menurut (Ahmad 2014), mengemukakan bahwa peranan penting pembelajaran sejarah sebagai bagian dari pendidikan karakter disebabkan oleh beberapa hal Pertama, banyaknya masalah yang merusak kepribadian Siswa, beragam masalah seperti tawuran, kecurangan dalam ujian, sampai pergaulan bebas yang kini masih merajalela. Kedua, tantangan global menuntut penyikapan yang bijak berbasis pada kearifan masyarakat. Karenanya perlu penguatan bagi masyarakat untuk 
menyikapi perubahan global melalui sejarah. Ketiga, pengembangan karakter memerlukan best practice keteladanan dari nilai-nilai ketokohan yang terkandung dalam pembelajaran sejarah. melalui pembelajaran sejarah, nilai-nilai keteladanan dan ketokohan dapat diinternalisasikan kepada Siswa.

Peranan pembelajaran sejarah sangat penting bagi pendidikan masyarakat Indonesia terutama dalam lingkungan Sekolah. Untuk itu, pembelajaran sejarah diajarkan mulai dari sejak SD, SMP, SMA, hingga perguruan tinggi, pembelajaran sejarah juga membantu manusia dalam menyelesaikan berbagai masalah karakter serta dapat membekali masa depan yang cerah dengan merujuk pada masa lalu. Materi sejarah yang dipelajari mengandung nilai-nilai kepahlawanan, ketokohan, kepeloporan, patriotisme, nasionalisme dan semangat pantang menyerah yang mendasari proses pembentukan watak dan kepribadian Siswa (Aman 2011).

Beberapa nilai ketokohan yang dapat digali dan dikembangkan melalui pembelajaran sejarah yang bermakna, Pembelajaran sejarah adalah mata pelajaran yang menanamkan pengetahuan, sikap dan nilai-nilai mengenai proses perubahan dan perkembangan masyarakat Indonesia dan Dunia dari masa lampau hingga sekarang (Agung, Leo \& Wahyuni 2013), maka dari itu memang sangat dituntut adanya kreativitas dari para guru Sejarah. Guru sejarah harus mengali dan mampu dalam mentransformasikan nilai-nilai tersebut pada Siswa, berdasarkan peran dari guru tersebut, Siswa dapat memahami apa yang mereka ketahui setelah mengikuti kegiatan pembelajaran sejarah. Sebagaimana yang dikemukakan oleh (Ahmad 2014). Salah satu keunggulan dalam pembelajaran sejarah yaitu adanya tokoh yang dijadikan panutan. Tokoh-tokoh sejarah menjadi best practice dalam menerapkan nilai-nilai keteladanan ataupun nilai luhur didalamnya. Oleh karena itu, keteladanan yang diharapkan dapat meningkatkan semangat kebangsaan pada Siswa.

Keberadaan Sekolah-sekolah Muhammadiyah tentunya akan lebih memudahkan dalam penanaman nilai-nilai keteladanan dan Kemuhammadiyahan. SMA Muhammadiyah 3 Surakarta sebagai Sekolah Muhammadiyah tentu saja sudah menerapkan nilai-nilai karakter Islam pada proses pembelajarannya yang sesuai dengan visi dan misi sekolah untuk mewujudkan siswa berkarakter Islam, meski demikian disana masih terdapat beberapa siswa yang memiliki perilaku yang kurang terpuji, seperti malas belajar, kurangnya minat siswa dalam pembelajaran, tidak disiplin dalam melaksanakan Sholat, kurang menghormati teman berbicara serta kurang sopan terhadap teman bahkan guru, dan lain-lain. Maka dengan adanya nilai-nilai keteladanan dari seorang tokoh yang memiliki pengaruh dalam sejarah pergerakan, terutama dalam Muhamammadiyah diharapkan dapat menanamkan keteladanan karakter dalam pembelajaran sejarah kepada siswa sebagai bekal dalam keseharian mereka, baik di sekolah maupun di lingkungan masyarakat (Arifin 2017).

Melalui keteladanan serta ketokohan mampu menjadikan suatu kepribadian yang baik dan bermanfaat bagi kehidupan sehari-hari, baik itu mulai pada lingkungan Sekolah, keluarga, serta masyarakat (Firdaus, Purnomo, and Ahmad 2018). Tugas Siswa sebagai generasi penerus, siswa juga harus memiliki kesadaran sejarah dalam penerapan pembelajaran sejarah perlu adanya pemahaman ketokohan dan keteladanan Buya Ahmad Rasyid Sutan Mansur, selain itu, peneliti juga akan melihat bagaimana implementasi pembelajaran sejarah dan sikap siswa mengenai ketokohan dan keteladanan Buya A. R. Sutan Mansur. Oleh karena itu penting untuk dilakukan penelitian tentang ImplementasiPembelajaran Sejarah Melalui Keteladanan Buya A. R. Sutan Mansur untuk dapat menerapkan keteladanan karakter dalam pembelajaran sejarah kepada siswa sebagai bekal dalam keseharian mereka, baik di sekolah maupun di lingkungan masyarakat.

Berdasarkan deskripsi di atas, menurut peneliti terkait implementasi pembelajaran sejarah melalui keteladanan Buya A. R. Sutan Mansur memiliki implikasi yang positif terhadap pengembangan karakter siswa. Hasil penelitian ini menunjukan bahwa 
implementasi pembelajaran sejarah melalui keteladanan ketokohan, dapat memberikan kontribusi yang signifikan terhadap karakter dan budaya bangsa bagi para Siswa. Hal ini senada dengan penelitian yang dilakukan oleh (Chaerulsyah 2014), yang menyatakan persepsi siswa terhadap keteladanan Pahlawan Nasional bersifat positif. Siswa mengenal sosok Pahlawan Nasional sebagai seorang yang gigih dalam berjuang, dan rela berkorban tanpa pamrih, bersikap jujur dalam memperjuangkan kemerdekaan Indonesia dalam upaya menegakkan kedaulatan. Maka dari itu timbul pertanyaan bagi peneliti sebgaimana yang dapat dirumuskan dalam rumusan masalah sebagai berikut:

1. Bagaimana Implementasi Pembelajaran Sejarah Melalui Keteladanan Buya Ahmad Rasyid Sutan Mansur di SMA Muhammadiyah 3 Surakarta.

2. Kendala Guru Dalam Implementasikan Pembelajaran Sejarah di SMA Muhammadiyah 3 Surakarta.

Pembelajaran Sejarah merupakan cabang ilmu pengetahuan yang menelaah tentang asal-usul dan perkembangan serta peranan masyarakat di masa lampau berdasarkan metode dan metodologi tertentu. Sejarah dapat dikatakan sebagai sebuah ilmu yang berusaha menemukan, mengungkapkan, serta memahami nilai dan makna budaya yang terkandung dalam peristiwa-peristiwa masa lampau (Mulyono Abdurrahman 1999). Sejarah merupakan mata pelajaran yang sangat berkaitan dengan pengembangan dan pembinaan sikap kebangsaan, semangat Nasionalisme, cinta tanah air, berjiwa demokrasi, dan patriotisme.

Keteladanan adalah Sebagaimana yang tercantum pada Kamus Besar Bahasa Indonesia diartikan sebagai sesuatu sikap atau tingkah laku dapat ditiru serta dicontoh juga dikemukakan yakni"teladan"dalam arti yang senada adalah bermakna memberikan suatu contoh (Noer Aly Hery 1999), Sedangkan keteladanan dalam cakupan luas, yaitu berbagai perkataan, sikap, dan perilaku yang melekat pada diri pendidik atau orang tua. Keteladanan juga diartikan sesuatu yang pantas untuk ditiru atau baik untuk dicontoh.

Dengan adanya metode keteladanan yang diterapkan dalam proses pendidikan yaitu ada dua bentuk, yakni secara langsung atau tidak dengan secara langsung (Asnelly llyas 1998). Secara langsung maksudnya yaitu seorang pendidik harus betul-betul mengaktualisasikan diri sehingga menjadi contoh teladan yang baik bagi semua siswa. Sedangkan dengan cara tidak langsung memiliki makna, bahwa seorang pendidik mampu mengaktualisasikan keteladanan terhadap siswanya dengan cara memberi tahu siswanya terkait kisah teladan baik itu berupa teladan dari para nabi, serta orang-orang besar, pahlawan bertujuan agar siswa dapat menjadikan serta menghayati keteladanan dan perjuangan tokoh-tokoh yakni sebagai suatu suri teladan dalam kehidupan mereka.

\section{METODE}

Dalam kajian ini metode yang digunakan adalah Kualitatif. Kualitatif yakni suatu pendekatan ilmiah yang mengungkapkan situasi sosial tertentu yang memdeskripsikan kenyataan secara benar, yang mana dibentuk oleh kata-kata didasarkan pada teknik pengumpulan analisis data yang relevan didapatkan dari situasi alamiah (J. Lexy Moleong 2008). Dengan pendekatan Discourse Analysis. Data dikumpulkan melalui observasi, wawancara secara mendalam, studi dokumentasi, Tekni Analisis data menggunakan analisis interaktif Milles dan Huberman (Miles 2007). 


\section{HASIL DAN PEMBAHASAN}

\section{A. Implementasi Pembelajaran Sejarah Melalui Keteladanan Buya Ahmad Rasyid Sutan Mansur di SMA Muhammadiyah 3 Surakarta}

Pada bagian ini dijelaskan hasil Implementasi Pembelajaran Sejarah Melalui Keteladanan Buya A. R. Sutan Mansur di SMA Muhammadiyah 3 Surakarta, di bagi dalam bahasan a.) Kondisi Pembelajaran Sejarah di SMA Muhammadiyah 3 Surakarta. b.) Implementasi Pembelajaran Sejarah Melalui Keteladanan Buya A. R. Sutan Mansur di SMA Muhammadiyah 3 Surakarta.

\section{Kondisi Pembelajaran Sejarah di SMA Muhammadiyah 3 Surakarta}

Pembelajaran sejarah di SMA Muhammadiyah 3 Surakarta sudah mengacu pada Silabus dan Kurikulum yang berlaku, dalam pelaksanaannya berjalan baik dan efektif walaupun selama Pandemi covid 19 dilaksanakan melalui Google Classroom dengan waktu 2x45 menit atau selama 90 menit. Pelaksanaan pembelajaran dilaksanakan guru Sejarah dalam pembelajarannya terlebih dahulu memperkenalkan tokoh Pergerakan Nasional yang berpengaruh dalam Sejarah serta Siswa di suruh memilih salah-satu tokoh dan kemudian menghafalkan moto dari tokoh tersebut dengan melakukan diskusi, presesntasi, serta Siswanya di suruh mengeksplorasi sendiri dan guru memberikan pertanyaan serta penegasan sehingga dalam proses pembelajaran Sejarah murid ada yang antusias tetapi juga ada yang kurang antusias, oleh karena itu dibutuhkan sebuah inovasi yang bisa mendongkrak minat siswa dalam belajar sejarah. kesempatan ini bagi peneliti sangat relevan ketika mengimplementasikan pembelajaran sejarah melalui keteladanan Buya A. R. Sutan Mansur di SMA Muhammadiyah 3 Surakarta sebagai solusi akan hal tersebut, ketika pelaksanaan pembelajaran dimulai, sikap yang ditunjukkan oleh Siswa tertib serta menghargai guru yang sedang mengajar dengan memperhatikan materi yang di sampaikan, serta dilengkapi oleh Sumber belajar Buku Sejarah Indonesia Siswa Kelas XI, Kemendikbud, Tahun 2016, Buku lain yang menunjang, Multimedia interaktif dan Internet (Buk Indah Rahmawati Akbar 2020).

Mengingat pentingnya pembelajaran sejarah dalam konteks pendidikan haruslah memberikan kontribusi pembentukan karakter dan identitas diri. Yang menjadi orientasi dalam pengembangan mata pelajaran sejarah di dunia, demi terwujudnya individu bangsa yang memiliki integritas tinggi dan sadar akan perkembangan bangsa (Kobrin, David, Ed Abbott, John Elinwood 1993). Pembelajaran Sejarah pada Sekolah Menengah Atas memiliki peran penting yang sangat strategis dalam pembentukan karakter Siswa, pembentukan karakter yang dimaksud adalah agar Siswa kelak menjadi warga negara yang bertaqwa kepada Tuhan Yang Maha Esa, bersikap Nasionalisme serta cinta tanah air.

Disamping itu, dijadikannya sejarah sebagai mata pelajaran di Sekolah pada dasarnya bertujuan agar Siswa menyadari adanya keragaman pengalaman hidup pada masing-masing masyarakat dan adanya cara pandang yang berbeda terhadap masa lampau untuk memahami masa kini dan membangun pengetahuan serta pemahaman untuk menghadapi masa yang akan datang (Isjoni. 2007).

\section{Implementasi Pembelajaran Sejarah Melalui Keteladanan Buya A. R. Sutan Mansur di SMA Muhammadiyah 3 Surakarta}

Implementasi pembelajaran sejarah melalui keteladanan Buya A. R. Sutan Mansur di SMA Muhammadiyah 3 Surakarta peneliti mendapati informasi ada tiga karakteristik masalah yang dihadapi Siswa dan guru di SMA Muhammadiyah 3 Surakarta yaitu, keterlibatan, Antusiame dan kurang Antusiame dalam pembelajaran Sejarah. Berdasarkan tiga karakteristik ini, sebuah"Inovasi” pembelajaran Sejarah telah di integrasikan dalam implementasi Pembelajaran Sejarah Melalui Keteladanan Buya A. R. Sutan Mansur di SMA Muhammadiyah 3 Surakarta, membawa keseimbangan dan 
menjadi penentu sejarah di Sekolah serta pengalaman belajarnya sebagai wahana yang dirancang untuk menyampaikan metode pengajaran Sejarah yang lebih kreatif. Dalam penelitian ini peneliti menggunakan Teori Enrichment Triad Model yang digagas oleh Joseph.S Renzulli. Dalam Enrichment Triad Model aktifitas yang dialami siswa dalam penerapannya terbagi menjadi Tiga tahapan, diantaranya adalah 1.) Tipe I General Explorator. 2) Tipe II Group Training Activities. 3) Tipe III Individual And Small Group Investigation of Real (Cony Semiawan 2004). Enrichment Model Triad terbagi tiga jenis pengayaan pada awalnya diimplementasikan dalam program pengayaan yang dirancang untuk Siswa yang berbakat secara Akademisi dan berbakat. Tetapi kebutuhan pembelajaran mendorong pendidik guna menjadikan Enrichment dalam menjembatani kelahiran bakat-bakat baru. Ada tiga tahap implementasi (Cony Semiawan 2004).

Tahap I dirancang untuk memperkaya intelektual Siswa dalam hal ini guru mengimplementasikan Pembelajaran Sejarah Melalui Keteladanan Buya A. R. Sutan Mansur di SMA Muhammadiyah 3 Surakarta ke dalam Rencana Pelaksanaan Pembelajaran Sejarah yaitu pada Kompetensi Dasar 3.4 Menghargai nilai-nilai sumpah pemuda dan maknanya bagi kehidupan kebangsaan di Indonesia pada masa kini. Indikator pencapaian Kompetensi Dasar meliputi: 1) Menghayati tumbuhnya ruh kebangsaan Indonesia 2.) Menganalisis Perjuangan Organisasi Pergerakan Kebangsaan 3.) Menganalisis proses penguatan jati diri bangsa. 4.) Meneladani nilainilai kejuangan dan perjuangan para pemuda dan pelajar.

Dalam perencanaan guru sejarah sudah menyusun perangkat pembelajaran berupa Rencana Pelaksanaan Pembelajaran (RPP), Berdasarkan hasil Observasi penelitian terhadap pelaksanaan pembelajaran Sejarah yang dilakukan selama Pandemi Covid 19 yakni melalui Google Classroom, adapun kegiatan awal pembelajaran yang dilakukan guru yaitu kegiatan awal terlebih dahulu melaksanakan kegiatan pendahuluan, kegiatan Inti dan kegiatan penutup. Kompetensi Dasar yang telah direncanakan dalam RPP oleh Ibuk Indah Rahmawati Akbar, S. Pd, selaku guru Sejarah, melaksanakan pembelajaran dalam enam kali pertemuan dengan alokasi waktu 2x45 Menit atau 90 Menit, lbuk Indah Rahmawati memanfaatkan waktu dan jam mengajarnya dengan sebaik mungkin melalui Google Classroom, maka disinilah pentingnya peranan guru untuk menajemen waktu serta mengelola pembelajarannya.

Pelaksanaan pembelajaran merupakan tanggung jawab guru dalam mengembangkan segala potensi yang ada pada Siswa, tujuan pokok proses pembelajaran Sejarah adalah untuk mengubah tingkah laku Siswa berdasarkan tujuan yang telah dirumuskan oleh guru sebelum proses kegiatan pembelajaran Sejarah berlangsung, guru sebagai katalisator artinya guru berperan untuk membantu Siswa menemukan kekuatan, talenta, serta kelebihan mereka, guru bertindak sebagai pembimbing, membantu mengarahkan serta mengembangkan aspek kepribadian, karakter dan emosi, aspek intelektual murid, sehingga murid bisa memahami bahwa proses pembelajaran yang benar adalah proses yang berkesinambungan (Utomo 2012).

Kegiatan ini merupakan bagian yang tidak terlepas dari materi yang ada dalam RPP guru, namun bersinergi dengan tujuan Kompetensi Dasar 3.4. Dalam hal ini guru mengimplementasikan pembelajaran sejarah melalui Keteladanan Buya A. R. Sutan Mansur di SMA Muhammadiyah 3 Surakarta dalam bentuk materi. Tipe I dan II bertujuan untuk memberi arah pada seluruh siswa dan memberikan dasar-dasar pada seluruh siswa untuk mengembangkan segala potensinya. Pada Tipe III harapannya Siswa bisa lebih termotivasi dalam mengembangkan pengalaman secara mandiri.

Tahap II mencakup bahan dan metode yang dirancang untuk mempromosikan proses berpikir. Dalam mengimplementasikan Pembelajaran Sejarah Melalui Keteladanan Buya A. R. Sutan Mansur di SMA Muhammadiyah 3 Surakarta tersebut dengan mode Singkronisasi terhadap masalah yang terjadi di era 
sekarang ini. Tujuannya agar bisa menjembatani dalam mengimplementasikan Pembelajaran Sejarah Melalui Keteladanan Buya A. R. Sutan Mansur di SMA Muhammadiyah 3 Surakarta sebagai pijakan dalam menyelesaikan masalah. Dalam arti bahwa guru menjadikan Siswa sebagai sosok Buya A. R. Sutan Mansur pada era sekarang ini. Guru memberikan masalah Kontemporer tujuannya agar dapat membuat Siswa mimiliki kemampuan untuk mengembangkan kreatifitas, inovasi, berfikir kritis, kemampuan untuk menyelesaikan masalah, kemampuan komunikasi dan kerja sama, serta kemampuan dalam mmanfaatkan teknologi dan informasi dan kemampuan komunikasi Siswa. Sehingga bisa menjembatani keberminatan pada Tahap III.

Tahap III melibatkan Siswa dengan memfokuskan siswa pada kegiatan mengembangkan pengalaman secara mandiri, dalam hal ini siswa diberikan kesempatan untuk bekerja secara mandiri dengan mengerahkan potensi masingmasing yang nantinya akan dapat dimanfaatkan dalam proses pembelajaran dalam mengambil peran sebagai wujud teladan bagi Siswa.

Pada bagian ini guru memberikan motivasi dari keteladanan Buya A. R. Sutan Mansur yang mampu menginspirasi kehidupan dalam mengimplementasikan pembelajaran sejarah melalui keteladanan Buya A. R. Sutan Mansur di SMA Muhammadiyah 3 Surakarta, guru memberikan tugas serupa terkait Pahlawan atau tokoh pejuang dalam Sejarah Pergerakkan Bangsa Indonesia, terutama dalam Muhammadiyah yang telah memberikan inspirasi sampai pada masa sekarang ini. Mengingat bahwa peristiwa sejarah tidak terlepas dari pengaruh para tokoh sejarah sebagai teladan, kepeloporan, dan pejuang (Revolusioner). Penulisan tersebut dilakukan dari berbagai sumber manapun. Siswa menyajikan dalam bentuk karya ilmiah.Tugas ini dimaksudkan supaya Siswa mendapatkan daya tarik, nilai-nilai keteladaanan tokoh, kepeloporan serta perjuangan dari tokoh-tokoh sejarah terdahulu dan menjadikannya sebagai tokoh inspirator yang dapat diserap nilai-nilai keteladanannya dalam kehidupan di masa yang akan datang. Sehingga dapat memberikan Stimulus dalam mengatasi ketiga masalah tersebut agar masalah tersebut dapat teratasi. Harapannya adalah agar Siswa memiliki bakat dalam menerapkan intelektual mereka dalam segala bidang, Tahap III memiliki tujuan dalam melibatkan tingkat kreatif yang tinggi.

Pembelajaran sejarah, yang dilaksanakan oleh guru Sejarah di SMA Muhammadiyah 3 Surakarta merupakan sarana yang tepat dalam mengimplementasikan pembelajaran Sejarah melalui keteladanan Buya A. R. Sutan Mansur di SMA Muhammadiyah 3 Surakarta, karena Siswa sudah dihadapkan pada situasi dan tempat yang formal dalam melakukan kegiatan pembelajaran. Hal ini sesuai yang dikemukakan oleh (Aman 2011), mengemukakan bhawa materi Sejarah merupakan bahan pendidikan yang mendasar bagi proses pembentukan dan penciptaan peradaban bangsa Indonesia di masa depan, serta adanya rasa solidaritas menjadi perekat bangsa dalam menghadapi ancaman disintegrasi bangsa Barat dengan ajaran moral dan ke arifan yang berguna dalam mengatasi krisis serta mengembangkan sikap bertanggung jawab dan memelihara keseimbangan dan keletarian lingkungan hidup.

Evaluasi atau penilaian pembelajaran dalam mengimplementasikan pembelajaran Sejarah melalui keteladanan Buya A. R. Sutan Mansur di SMA Muhammadiyah 3 Surakarta merupakan komponen terakhir dari pembelajaran Sejarah. Penilaian merupakan salah satu bagian yang penting dalam mengevaluasi proses belajar mengajar di Sekolah. Kegiatan evaluasi dilakukan untuk melihat kembali tingkat pemahaman Siswa terhadap materi yang telah diberikan oleh guru. Demikian juga dalam konteks implementasi pembelajaran Sejarah melalui keteladanan Buya A. R. Sutan Mansur di SMA Muhammadiyah 3 Surakarta penting untuk dilakukan penilaian agar mengetahui kembali tingkat pemahaman Siswa dalam mengaplikasikan nilai-nilai keteladanan tersebut dalam kehidupan sehari-hari. 
Guru Sejarah Ibuk Indah Rahmawati Akbar, S.Pd, dalam Rencana Pelaksanaan Pembelajaran (RPP), merencanakan evaluasi pembelajaran Sejarah dengan menggunakan beberapa model penilaian. Model pembelajaran tersebut dirancang dalam Rencana Pelaksanaan Pembelajaran (RPP), evaluasi hasil belajar dapat terlaksana dengan baik apabila dalam pelaksanaanya berpegang pada tiga prinsip yaitu prinsip keseluruhan, kesinambungan dan prinsip objetivitas, hal ini didasarkan pada aspek yang digunakan sebagai penilaian hasil belajar berpedoman pada aspek Kognitif, Afektif dan Psikomotorik, yang mana pada aspek Kognitif (pengetahuan) guru Sejarah di SMA Muhammadiyah 3 Surakarta menggunakan penilaian tes tertulis, penugasan, sedangkan dalam aspek keterampilan menggunakan analisis yang telah dirangkum oleh Siswa.

\section{B. Kendala Guru Dalam Implementasikan Pembelajaran Sejarah di SMA Muhammadiyah 3 Surakarta}

Dalam mengimplementasikan pembelajaran Sejarah melalui keteladanan Buya A. R. Sutan Mansur di SMA Muhammadiyah 3 Surakarta, bukanlah sebuah proses yang dapat dilaksanakan secara singkat. Dalam arti bahwa, setelah Siswa mengetahui tentang Nilai-nilai keteladanan Buya A. R. Sutan Mansur. Perlu adanya keterpaduan dan kesinambungan dari berbagai pihak, agar Siswa berusaha menanamkan nilai-nilai keteladanan tersebut. Pada hakekatnya Siswa di SMA Muhammadiyah 3 Surakarta sudah menunjukkan karakter yang baik, kendala yang dihadapi oleh seorang guru ialah Siswa belum sepenuhnya berusaha menanamkan nilai karakter dalam dirinya. Meskipun sesungguhnya Siswa telah mengetahui nilai-nilai keteladanan tersebut, disamping itu guru telah berupaya untuk terus menanamkan dan memberikan keteladanan bagi Siswanya, supaya bisa melakukan perbuatan yang mencerminkan nilai-nilai keteladanan tersebut.

Pada tingkat perencanaan kendala dalam penyusunan Rencana Pelaksanaan Pembelajaran (RPP) tidak memiliki kendala, dalam penyusunan tujuan pembelajaran juga tidak terdapat kendala yang sama sekali. Dalam proses pembelajaran Sejarah guru menggunakan Buku sumber materi sejarah yaitu Buku Sejarah Indonesia Siswa Kelas XI, Kemendikbud, Tahun 2016, Buku LKS, dan sumber Multimedia interaktif dan Internet, kendala lain yang muncul dalam implementasi pembelajaran Sejarah Melalui keteladanan Buya A. R. Sutan Mansur di SMA Muhammadiyah 3 Surakarta muncul pada tingkat ke aktifan Siswa yang mana tingkat keaktifan Siswa cukup baik dan sejauh ini efektif dalam pembelajarannya, akan tetapi sebagian Siswa dalam pembelajaran Sejarah melalui Google Classroom Kelas XI SMA Muhammadiyah 3 Surakarta, ada Siswa yang antusia, ada juga Siswa yang kurang antusias dalam pembelajaran, oleh karena itu, keaktifan Siswa dalam proses pembelajaran Sejarah ikut berpengaruh terhadap diri Siswa itu sendiri (Buk Indah Rahmawati Akbar 2020).

Kendala lainnya juga terdapat pada alokasi waktu yang digunakan oleh guru Sejarah dalam menyampaikan materi pembelajaran Sejarah kepada Siswa waktunya terlalu singkat sehingga terkendala pada waktu pelaksanaan pembelajarannya, sehingga dalam kegiatan pembelajaran tidak berjalan secara baik, karena alokasi waktu pelajaran Sejarah juga menjadi hambatan yang serius dalam proses pembelajaran Sejarah karena selama Pandemi Covid 19 ini pembelajaran dilaksanakan melalui Google Classroom, berdasarkan hal tersebut diharapkan kepada pihak Sekolah ataupun pemerintah supaya mencari solusinya bersama (Buk Indah Rahmawati Akbar 2020).

Selain dari beberapa kendala di atas, kendala lainnya juga terdapat kendala pada buku Sumber pembelajaran, yang mana buku sumber kurang memadai dalam proses pembelajaran Siswa, sehingga kurangnya materi yang akan diselesaikan dalam pembelajaran, disamping itu juga di dukung oleh sumber lainnya Buku lain seperti LKS, dan juga di dukung oleh sumber Multimedia interaktif serta Internet. hal tersebut sudah 
sesuai dengan penilaian yang ada di dalam perangkat pembelajaran pada Kurikulum 2013, yang mana proses penilaian diambil dalam 3 aspek yaitu, pengetahuan, sikap dan keterampilannya (Buk Indah Rahmawati Akbar 2020).

\section{SIMPULAN}

Implementasi Pembelajaran Sejarah Melalui Keteladanan Buya A. R. Sutan Mansur di SMA Muhammadiyah 3 Surakarta sudah berjalan cukup baik dan efektif, selama Pandemi Covid 19 melalui Google Classroom, dalam pembelajaran Sejarah guru sudah menyusun perangkat pembelajaran yang terdiri dari Silabus, RPP dan penerapan nilai-nilai keteladanan Buya A. R. Sutan Mansur dalam pembelajaran guru Sejarah sudah memunculkan nilai-nilai keteladanan Buya A. R. Sutan Mansur yang terdiri dari nilai Religius, nilai nasionalisme, nilai kerja keras, nilai kemandirian dan keteguhan pendirian yang sangat tinggi, akan tetapi juga memiliki kendala, yakni sumber belajar yang kurang memadai, waktu pembelajaran yang kurang mecukupi, sedangkan materi pelajarannya banyak, dikarenakan juga karakter Siswa yang berbeda-beda.

\section{DAFTAR PUSTAKA}

Agung, Leo \& Wahyuni, Sri. 2013.“Perencanaan Pembelajaran Sejarah. No Title.” In , 10. Yogyakarta: Ombak.

Ahmad, Tsabit Azinar. 2014."Kendala Guru Dalam Internalisasi Nilai Karakter Pada Pembelajaran Sejarah." Jurnal IImiah Kependidikan.

Aman. 2011. Model Evaluasi Pembelajaran Sejarah. Yogyakarta: Ombak.

Amin. S. 2010. Pewarisan Nilai Sejarah Lokal Melalui Pembelajaran Sejarah Jalur Formal Dan Informal Pada Siswa SMA Di Kudus Kulon."Tesis".Surakarta. Pendidikan Sejarah UNS.

Arifin, Zaenal. 2017."Implementasi Pendidikan Karakter Islami Pada Kegiatan Ekstrakurikuler" Hizbul Wathan"(Studi Empirik Di SMA Muhammadiyah 3 Surakarta).“.Universitas Muhammadiyah Surakarta.

Asnelly llyas. 1998. Mendambakan Anak Shaleh; Prinsip-Prinsip Pendidikan Anak Dalam Islam. Bandung: al-Bayan.

Buk Indah Rahmawati Akbar. 2020."Wawancara Pribadi Dengan Guru Sejarah SMA Muhammadiyah 3 Surakarta." Jl. Kolonel Sutarto No. 62, Jebres, Kec. Jebres, Kota Surakarta.

Chaerulsyah, Edwin Mirza. 2014. "Persepsi Siswa Tentang Keteladanan Pahlawan Nasional Untuk Meningkatkan Semangat Kebangsaan." Indonesian Journal of History Education 3 (1).

Cony Semiawan. 2004. Perspektif Anak Berbakat. Jakarta: Grasindo.

Firdaus, Aufa Hasan, Arif Purnomo, and Tsabit Azinar Ahmad. 2018. "Kesadaran Sejarah Siswa Terhadap Ketokohan dan Keteladanan Sunan Kudus Di MA Qudsiyyah Kudus Tahun Pelajaran 2017/2018." Indonesian Journal of History Education, 6 (2): 150-61. https://doi.org/E-ISSN: 2549-0354; P-ISSN: 22526641.

Isjoni. 2007. Cooperatif Learning: EFektivitas Pembelajaran Kelompok. Bandung: 


\section{ALFABETA.}

J. Lexy Moleong. 2008. Metode Penelitian Kualitatif. Bandung.: PT. Remaja Rosda Karya.

Kobrin, David, Ed Abbott, John Elinwood, and David Horton. 1993."Learning History by Doing History",Educational Leadership 50:39-41.

Miles, Mattew B dan Amichael Huberman. 2007. Analisis Data Kualitatif Buku Sumber Tentang Metode-Metode Baru. Edited by Terjemahan Tjetjep Rohendi Rohisi. Jakarta: Universitas Indonesia.

Mulyono Abdurrahman. 1999. Pendidikan Bagi Anak Berkesulitan Belajar. Jakarta: Rineka Cipta.

Noer Aly Hery. 1999. IImu Pendidikan Islam, Cet. II. Jakarta: Logos.

Sukmadinata, Nana Syaodih. 2009. Metode Penelitian Pendidikan. Bandung: : Remaja Rosdakarya.

Suryadi dan Budiansyah. 2009. Paradigma Pembangunan Pendidikan Nasional Konsep, Teori Dan Aplikasi Dalam Analisis Kebijakan Publik. Bandung: Widya Aksara Press.

Utomo, C. B. 2012. "Model Kepemimpinan Dan Suasana Akademik Dalam Pembelajaran Sejarah SMA Di Kota Semarang." Pramita Historical Studies Journal 22, No.1: 98. 